\title{
The Celts in Antiquity: Crossing the Divide Between Ancient History and Archaeology
}

\author{
Os celtas na Antiguidade: cruzando a \\ divisão entre História Antiga e arqueologia
}

Raimund $\operatorname{Karl}^{*}$

\section{Resumo}

Entre os atores históricos da Antiguidade estão as populações do Noroeste e Centro da Europa, denominadas "Celtas" pelos autores clássicos. Embora iletradas, em sua maioria, até por volta do século I a.C./d.C., foram mencionadas por autores estrangeiros como Políbio, César, Estrabão, Diodoro e outros. O estudo dessas sociedades "célticas", portanto, dificilmente se sustentaria com base apenas na historiografia clássica, mas precisa considerar a Arqueologia. As fontes históricas e arqueológicas são dificilmente reconciliáveis, mesmo quando há temas comuns. Este artigo examina as diferenças, mas também as semelhanças entre as várias sociedades "célticas" da Europa e seus vizinhos, e os usos do termo "Celta". O estudo de caso das escavações de Meillionydd, no Norte do País de Gales, é usado para demonstrar como diferentes tipos de material e escalas local e global podem integrar-se em um único e coerente modelo explanatório.

Palavras-chave: celtas; antiguidade; Europa; Britânia; analogia.

\section{Abstract}

One historical actor in Antiquity are the populations of Western-Central Europe, commonly called 'Celts' by classical authors. Themselves (mostly) illiterate until approximately the 1 st century $\mathrm{BC} / \mathrm{AD}$, reports about them, written by foreigners like Polybius, Caesar, Diodorus and others have survived. The study of 'Celtic' societies thus can hardly rely on classical historiography, but is mainly based on archaeology. Historical sources and archaeology are difficult to reconcile, even if common themes can be identified in both types of sources. This article examines the differences, but also similarities between the various 'Celtic' societies of Europe and their neighbours, and the use of the term 'the Celts'. The case study of the excavations at Meillionydd in North Wales is used to demonstrate how different types of source material and local and global scales can be integrated into a single, coherent explanatory model.

Keywords: Celts; Antiquity; Europe; Britain; analogy.

\footnotetext{
* Bangor University, Bangor, Wales, UK. r.karl@bangor.ac.uk <https://orcid.org/0000-0001-5832-8656>
} 


\section{The Use of the Term ‘Celts’ in Antiquity}

The Celts first appear in historical sources after, around 600 BC, Phocaean Greeks advanced into the western Mediterranean and established their colony

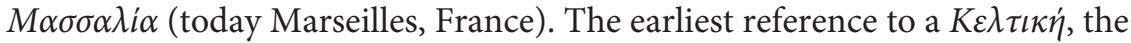
land of the 'Celts', located in the hinterland of $M \alpha \sigma \sigma \alpha \lambda i \alpha$, is usually ascribed to Hecataeus of Milet (c. $500 \mathrm{BC}$ ), although this only survives in a reference in a text from the 6th century AD by Stephanos of Byzantium (Tomaschitz, 2002, pp. 15-16). The Histories of Herdot of Halicarnassus, written early in the second half of the 5th century $\mathrm{BC}$, are the oldest surviving source mentioning the 'Celts'. Indeed, Herodot mentions 'Celts' twice. He first refers to them $(2,33)$ as living in the far West of Europe, beyond the Pillars of Heracles (the Strait of Gibraltar), and that the Danube has its sources there near a city called

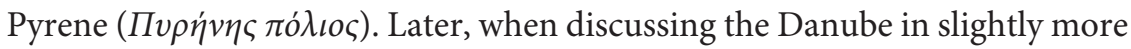

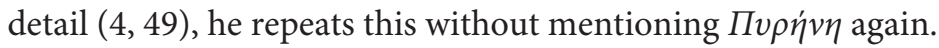

Whether Herodot (and/or his sources) actually knew much about the real geography and ethnography of Western and Central Europe or not matters little, though. After all, the presence of Celts in Northern Italy in the 4th century BC (Ps.-Scylax c. 18 f.), and also on the Greek mainland as mercenaries in the service of Dionysios I. of Syracuse, sent by him to support Sparta in 369/8 BC (Xenophon Hell. 7, 1,20 and 31; Diodorus 15, 70,1), is attested in contemporary sources. Also, both Plato in the first and Aristotle in the second half of the 4 th century BC already refer to 'the Celts' as one as the main barbarian peoples of the ancient world, sufficiently well-known to need no further explanation as to who they are and where they live; and Ptolemy I. Soter reports that Alexander the Great met ambassadors of Celts (probably living somewhere in the Northern Balkans; Hofeneder, 2005, pp. 49-51) on the lower Danube in 335 BC (Strab. Geogr. 7, 3,8). Equally famously, the Semnones, a tribe usually considered to be 'Celtic', had sacked Rome around 390 BC (Livy, $\mathrm{Ab}$ urbe condita 5, 35-48; Polybius, Hist. 2, 18), possibly following an earlier 'Celtic migration' into formerly Etruscan areas of various 'Celtic' tribes dated by Livy (Ab urbe condita 5, 33) to the 6th century BC.

Thus, as early as the mid-4th century BC at the very latest, the term 'Celts' had become established as the name used in classical Greek ethnography for barbarian communities inhabiting much of Europe, from the coast of the Atlantic Ocean, across much of Western and Central Europe (including considerable parts of the Northwestern shores of the Mediterranean Sea) and down into the Balkans. That made 'the Celts', from the perspective of classical 
ethnography, one of the major circummediterranean barbarian 'peoples', alongside other major players like the Thracians, Scythians, Persians, Carthaginians, and Iberians (e.g. Tomaschitz, 2002, p. 18). The name, and its rough Latin equivalent, 'Gauls', then stuck until much of what had been the $K \varepsilon \lambda \tau \iota \kappa \eta$ was conquered and integrated into its Empire by Rome, or became 'germanised' North of the Danube and East of the Rhine, with its use slowly fading out from then onwards.

\section{The Rediscovery of the ‘Celts’ by Modern Scholarship}

The name 'Celts' was rediscovered by modern antiquarian scholarship, mainly from the early 18 th century onwards, and quickly gained currency as the generic scholarly term used as an 'ethnic' identifier as well as a classificatory technical term for the (Later) Prehistoric - that is, mainly pre-Roman - inhabitants of much of Central and Western Europe. As the various specialised historical humanities - historical linguistics, history itself, art history and archaeology, etc. - started to split off general antiquarianism, mostly over the course of the 19th century, each thus inherited the term from the antiquarian tradition and started to define it for itself based on the sources for each of these disciplines, a practice which still continues (Karl, 2012, pp. 44-45).

Historical linguists, for instance, realised that some languages still spoken in or shortly before the present, like Irish and Scottish Gaelic, Manx, Welsh, Cornish and Breton, shared many characteristic features and a large percentage of their vocabulary with the languages attested as having been spoken in at least many areas which were considered to have been 'Celtic' by classical ethnography. These observable linguistic similarities, they interpreted as indicating a close ontogenetic relationship between these languages; and thus, applying the then (and still) popular 'Stammbaum' (genealogical) model of language evolution, classified the languages spoken in the present as 'descendant' languages of those spoken by 'Celts' in Antiquity. Thus, based on historical precedence, they called the 'language family' thus identified the 'Celtic' languages, and arrived at the definition that a 'Celt' is someone speaking such a language, whether in the past or the present (e.g. Dillion quoted in James, 1999, p. 81; Koch et al., 2007, p. 3).

Scholars in others of the emerging specialist disciplines did exactly the same, only based on the sources for their respective disciplines. Thus, art historians, for instance, identified a particular art style, which was popular in large areas of Europe from roughly between $450 \mathrm{BC}$ until the high middle ages (with 
a revival in modernity) as 'Celtic' art; for the very same reason: this art style had been widely in use in classical Antiquity, mainly in those areas of Europe

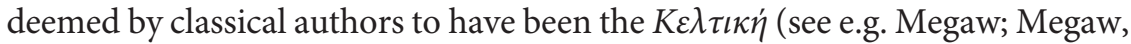
2001, pp. 12-23). Similarly, a 'Celtic' archaeology was defined by archaeologists based on partially the same, partially other features of material culture than merely the artistic decoration of tangible objects, resulting in the (late) Hallstatt and the La Tène 'cultures' of (Later) European Prehistory (c. 12th/8th century $\mathrm{BC}-1$ st century AD) being considered to be 'Celtic' by many archaeologists (see on this also Collis, 2003, pp. 71-92), with some of the latter 'culture' surviving, at least in parts of the British Isles, to perhaps as late as the 12th or even 13th century AD. Again, this was mainly done for the same reasons: the turn from Hallstatt to La Tène can be dated to roughly $450 \mathrm{BC}$, and both cultures

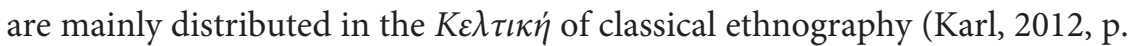
49 , Figure 2.3), particularly in the 6th and early 5th century BC from the hinterlands of $M \alpha \sigma \sigma \alpha \lambda i \alpha$ to the sources of the Danube and down its course into the Balkans. And the discipline of (ancient) history also stuck to its sources: for ancient historians proper, a 'Celt' was someone who either as an individual was referred to in classical sources as a 'Celt', or was a member of a community which was considered to be 'Celtic' in them.

To complicate matters even further, other (emerging) academic disciplines, like medieval and modern history, medieval and modern literature, historical musicology etc. also developed their own, secondary definitions of the 'Celtic'. It appeared sensible, at least from the perspective of each of these disciplines, to call the histories, literatures and music of more recent Irish, Scottish, Welsh, Breton etc. communities 'Celtic', too.

\section{DisCIPLINARY Divides AND INTERDISCIPLINARY INTERPRETATION}

Since all these disciplines, or at least numerous individual scholars in each of them, also communicated and still communicate with each other across disciplinary boundaries, a rather awkward, polysemous, and overall fuzzy modern collective scholarly definition of the terms 'Celts' and 'Celtic' emerged in parallel to these individual disciplinary developments. A 'Celt' can be someone who lived c. 1200 BC somewhere in the Balkans, about whom we know nothing other than that he used a particular kind of Prehistoric ('Hallstatt') material culture, as much as someone in the present who speaks English as his mother tongue, uses 'globalised' modern material culture, has African genetic ancestry, but plays the bagpipes and considers himself a proud 'Celt' by merit 
of having been born and bred in Scotland. Obviously, the connections between both of these two 'Celts' are tenuous at best, via a long chain of (mostly scholarly) loose cultural associations (Karl, 2012, pp. 44-48), and they most likely have nothing in common with each other whatsoever.

As long as disciplines keep themselves strictly separate, this is no problem. It may, however, become a considerable issue if interdisciplinary work is attempted, and especially if evidence from different disciplines is used for the purpose of drawing general conclusions about 'the Celts'. This problem, naturally, is most evident, but at the same time least relevant, when taking two 'Celts' from the extreme ends of the spectrum covered by this very wide general definition: one cannot arrive at any meaningful conclusions about the one by drawing on evidence about the other, since they quite obviously have nothing significant in common. Thus, no archaeologist in their right mind would argue that the individual living c. 1200 BC on the Balkans also played the bagpipes, just because both he and someone in the present who does play bagpipes are called 'Celts'; nor vice versa any modern musicologist assume that the Scottish bagpipe player would be using Hallstatt material culture for the same reason. Nor would any scholar draw general conclusions about 'the Celts' from those two sources, because the only actual conclusion he could arrive at is that they have nothing in common.

The problem is much less evident, but much more relevant, where the

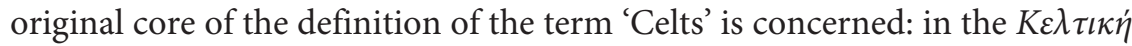
of classical Antiquity. It is in this original core area, where interdisciplinary work between scholars and the traditional core disciplines of wider 'Celtic Studies', that is ancient history, historical linguistics, archaeology, and art history, not just happens quite frequently, but is arguably necessary. After all, the respective source corpora of the different academic disciplines studying 'the ancient Celts' leave many gaps, and have considerable and quite different limitations as to what conclusions, whether disciplinary specific or general, can reliably be drawn from them.

\section{The Question of $\Pi v \rho \eta ́ v \eta$}

For instance, whether Herodot's $(2,33)$ report that the Danube has its

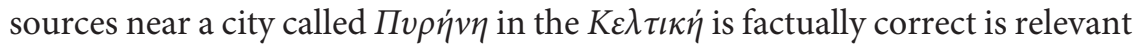
both for ancient history and for archaeology, but cannot be reliably established by either discipline on its own. 
For ancient history, it is relevant because if it is factually correct, it would indicate that relatively detailed knowledge of the real geography of the central and western European Barbaricum was much more developed in the mid 5th century BC than is normally assumed. But ancient history, on its own, cannot establish whether this is the case: Herodot (and/or his sources) may well have mistakenly assumed that the Danube had its sources in the Pyrenees, as Aristotle (Meteorologica 1,13) clearly does. But equally, Aristotle may have

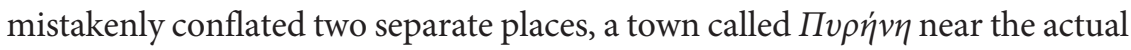
sources of the Danube, and the Pyrenees mountains, either because these two places just happened to have very similar names; or because by his time, the town of $\Pi v \rho \eta v \eta$ had long been abandoned and forgotten, misleading Aristotle and his contemporaries into locating the sources of the Danube in the Pyrenees.

For archaeology, it is relevant because there is, of course, a town, and a very special one at that for Central European Iron Age archaeology, near the actual sources of the Danube, the Heuneburg (see e.g. Krausse et al., 2016). Located roughly where the Danube becomes navigable, it was fortified as the only known exemplar of its kind north of the Alps with a Greek-style mudbrick wall roughly in the middle of the 6th century BC, indicating exceptionally close contacts with the Mediterranean during that time. Also significantly, it was abandoned in the 2 nd half of the 5th century BC. Prehistoric archaeology on its own, however, cannot recover the name of this town. Nor can it determine whether it was so significant that it was even (reasonably well) known (at least by name and rough location) in Greece in the 5th century BC; or whether it was just one of many late Hallstatt towns which, via many intermediate steps in a mostly 'indigenous' Western European trade and exchange network (the 'Hallstatt culture'), had connections to $M \alpha \sigma \sigma \alpha \lambda i \alpha$ and thus could import some Mediterranean goods and once, in an otherwise singular event, someone with knowledge of Greek architecture.

This makes it extremely tempting to cross the disciplinary boundaries between ancient history and archaeology to support the hypothesis that the

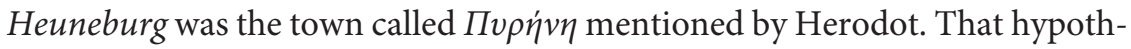
esis is indeed necessary, at least as long as we cannot conclusively determine whether it is true or not: after all, that Herodot reports that the sources of the Danube are near a (significant) town and there was in fact a (significant) town with Greek contacts near them in his time creates a considerable probability that Herodot actually knew of its existence. Thus, when trying to explain Greek contacts with the Central European Barbaricum, and vice versa the relationship between Southern Germany and Greece in the 6th-5th century BC, we 
must at least seriously consider the possibility that both (at least some) people living in Greece and (some) living in Southern Germany were reasonably well aware, not just about each other's existence, but about each other's politics, trade needs, customs, philosophy, religion, etc.

Moreover, it creates at least a distinct possibility that indeed, people were living at the Heuneburg who shared some characteristics with other people living in the far West of Europe which, from a Greek perspective, made all of them appear similar enough to refer to them by a common name, 'Celts', but distinct enough from others like 'Scythians', 'Thracians' etc. Of course, we do not know whether that was that they spoke languages which sounded similar, or used material culture or art which looked similar, had customs which seemed similar to Greek observers, or only predominantly had a similar skin or hair colour differing from that of other Barbarians. Which gets us back to disciplinary divides and interdisciplinary interpretations:

\section{Herodot's Method and Interdisciplinary Analogical Reasoning}

One of the biggest issues for all disciplines studying the ancient 'Celts' is the incompleteness of their sources. Thus, many aspects of the 'Celtic' past must remain unknown if relying on the sources of any single discipline.

However, many gaps in our knowledge may be filled, however tentatively, by means of the method used by Herodot $(2,33)$ when he first mentions both the Danube and the 'Celtic' town called $\Pi v \rho \dot{\eta} v \eta$ he reports as being located close to its sources: analogy. Because, after all, the passage which contains this information isn't about Europe at all, nor about the Danube, its course, or its sources, but is actually about Africa and more specifically about the Nile, its course, and the location of its sources. Regarding those, he says that it is well-known that the'I $\sigma \tau \rho \varsigma$ has its sources in the far West, and from there runs through the middle of Europe, and that thus, "judging the unknown from the known", that the Nile probably also has its sources in the far West and runs through the middle of Lybia.

Where the study of the 'Celts' (and more generally, the indigenous populations of Western and Central Europe) in Antiquity is concerned, archaeology is the 'leading' academic discipline for a number of reasons. Firstly, it has by far the most abundant sources: the finds and features left behind by later Prehistoric populations in Western and Central Europe number literally in the billions, even if we restrict ourselves to just the $K \varepsilon \lambda \tau \iota \kappa \eta$ as defined by classical authors, rather than considering the whole area of distribution of the Hallstatt and La Tène cultures from c. 1200 BC to perhaps as late as, in the British Isles, 
c. AD 1200. Its sources also allow to examine most aspects of life, at least all which leave any material traces. Also, its sources, at least by and large, were produced and deposited by the 'Celtic' populations themselves, rather than, as e.g. classical historiography, by members of other communities, and indeed mostly such who lived far, far away from the societies they describe and in many cases never actually had visited. And of course, while certainly not often created without any intention or agenda by their makers, archaeological sources only very rarely, if ever, as biased as historical sources tend to be by a particular author's agendas and ideology.

Yet, the mute stones (and other material remains) archaeologists find do not speak, which makes interpreting archaeological evidence particularly complicated. Thus, even at its most basic level, for the initial interpretation of the (likely) function and naming of the objects it studies, archaeology has to rely on analogical reasoning (Johnson, 1999, pp. 48-63; Bernbeck, 1997, pp. 85108): if we find (most often heavily corroded and fragmentary) remains of a thin, oblong Prehistoric bronze or iron object with the remains of a heft on one end, two roughly parallel cutting edges, and a point on the other end, we interpret its function as and call it a sword. Yet, we do not know whether that particular object actually was (used as) a sword, it just looks roughly what swords look like today, and thus use the known function and name of swords from historical periods to judge the unknown Prehistoric object. Similarly, if we want to interpret the archaeology of a particular settlement, or indeed the constitution of an even larger community, or the makeup of a society or polity as a whole, we must judge all that is unknown about it from something that is already known; and for that, we mostly use analogical reasoning.

The archaeological sources themselves just constrain what analogies can and cannot be used, with the analogical explanations flatly contradicted by the archaeological evidence having to be rejected. The principle can be illustrated

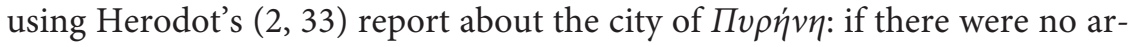
chaeological evidence for a (rather important) town (with proven contacts with the Greek world) near the actual sources of the Danube in the 6th-5th century $\mathrm{BC}$, we would not even remotely countenance the idea that Herodot might have accurately reported a known true fact about the actual geography of Western Central Europe. But because there is archaeological evidence of such a town actually having existed in his time in the actual place he describes, we can and must consider the possibility that this town is the one Herodot men-

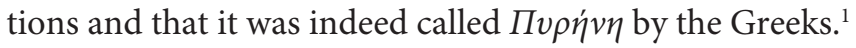




\section{Problems with Using 'Celtic’ Interdisciplinary Analogies}

Using sources like Herodot's $(2,33)$ report about a town called $\Pi v \rho \eta \dot{v} \eta$ near the sources of the Danube in the land of the 'Celts' appears rather uncontroversial at first glance: after all, at least if Herodot was indeed accurately reporting a known and, at least in his time, true fact, we have a historical record, both of positive knowledge of the existence at its actual location, and presumably also of the actual name (at least in its Greek rendering), of this town.

But (at least near-) contemporary historical sources accurately reporting true facts about something in what is, at this time, still effectively Prehistoric Europe are exceedingly rare and mostly tell us very little. Even where we have such reports, their accuracy is always at least questionable, as the example of

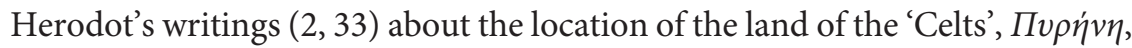
and the sources of the Danube amply demonstrates.

This is even the case with much more extensive reports about 'Celtic' populations of Western and Central Europe written by authors who actually had first-hand knowledge of the 'Celtic' populations and lands they described: while what Caesar reports (e.g. in De Bello Gallico 1, 16-20) about the officials, political systems, and political intrigues within the Aedui is highly likely to be reasonably accurate, it applies just to the Aedui in the immediate context of the overture to Caesar's Gallic wars. His excursus on the customs, politics, social system etc. of the Gauls (De Bello Gallico 6, 11-20), on the other hand, is obviously very generalised, simplified and it isn't even clear to what parts of Gaul or which Gallic communities (civitates or their sub-units) it actually applies, not even at the time when Caesar was in Gaul. This is not just evident from the fact that in the first two sentences of his commentaries (De Bello Gallico 1, 1,1-2), he says that the three parts of Gaul are inhabited by different peoples - the Belgae, the Aquitani and the Galli, who in their own language call themselves Celtae - and that these differ from one another in language, institutions, and laws. It is also evident from that, when he gives details on specific Gallic communities and their institutions or laws (e.g. De Bello Gallico 1, $2-4 ; 1,16-17 ; 2,4 ; 2,28$; etc.), they frequently at best remotely resemble his generalised description of Gaulish society in the excursus (De Bello Gallico 6, 11-20) and show significant differences even within the three 'peoples' mentioned in the initial sentence of his text (De Bello Gallico 1, 1,1). And that is even before one looks into the archaeology of Caesarian Gaul, which in itself is quite diverse. 


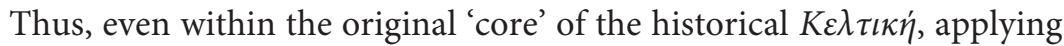
even information gained from the historical writings of contemporary eyewitnesses to anything other than the precise context they had actually observed - which often are difficult or even impossible to locate with a reasonable degree of accuracy - is fraught with difficulties. Applying it to anything beyond that immediate context, whether in space or time, is no more than an - at best tentative - analogy. And the further the distance between the source of the analogy becomes, the more tentative its application becomes.

At this point, we have to return to the different definitions which have been chosen by the different disciplines who study the 'Celts' for what they consider 'Celtic', because, after all, they have not been chosen entirely at random, but for (hopefully mostly well-considered) reasons. As much as the historical linguists have defined the 'Celtic' languages based on observable similarities in the linguistic evidence, so have the 'Celtic' Hallstatt and La Tène cultures of archaeology been defined based on observable similar features in the archaeological evidence, etc. Thus, these shared similarities, whether in language, material culture, art, or other kinds of evidence, indicate a certain continuity and contiguity of at least some cultural traditions, at least those which led to the similarities observable in the evidence. This creates the possibility that not just the directly observably shared cultural traditions may have been shared between the culturally connected communities, but other traditions, which may not be directly observable, may also have been shared between them; through both space and time.

Thus, even generic descriptions, like that of Caesar (De Bello Gallico 6, 11-20) of Gaulish societies, or even more generalised models derived from them and other comparable sources, may be tentatively applicable as an analogy in any attempt to explain the structure and makeup of much earlier societies in another part of Europe, e.g. to Hallstatt societies in Southern Germany or even the Balkans in the 10th century BC. Equally, linguistic evidence attested only a millennium or more later, or literary sources like Early Medieval epics or lawtexts from the British Isles, or general models derived from them, can be applied as analogies in attempts to explain e.g. Late Bronze and Iron Age British, or even late Prehistoric archaeological evidence in parts of Central and Western Europe. Where the archaeological material culture links, at least to some extent, the historical $K \varepsilon \lambda \tau \iota \kappa \eta \dot{~ w i t h ~ e a r l i e r ~ c o m m u n i t i e s ~ i n ~ m u c h ~ o f ~}$ Central and Western Europe, (closely) related languages link the Early

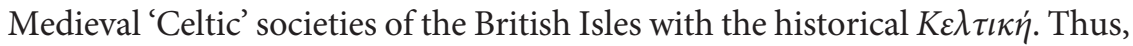
as long as it is properly recognised that these sources, however much later and 
from however far away they actually may come from, can only be used for analogical reasoning; and that whatever information is contained in them must be discarded if it is incommensurable with and thus contradicted by the archaeological evidence that it ought to explain; crossing the divide between disciplines by interdisciplinary analogical reasoning is possible.

\section{Applied Analogical Interdisciplinary Reasoning: 'Celtic' Courts}

To demonstrate this, in the second part of this paper, I will be crossing various disciplinary divides by using analogical interdisciplinary reasoning to explain the archaeology of a site Kate Waddington, Katharina Möller and I have been excavating for the last decade in Northwest Wales, the Late Bronze and Iron Age double ringwork enclosure (occupied from c. 800-200 BC) of Meillionydd. Since I have already repeatedly discussed the archaeology of the site (e.g. Karl, 2018; Karl, forthc.), I will only give a very quick summary of its archaeology here.

Figure 1 - Overview of the results of the excavations at Meillionydd, Llŷn, Northwest Wales, UK.

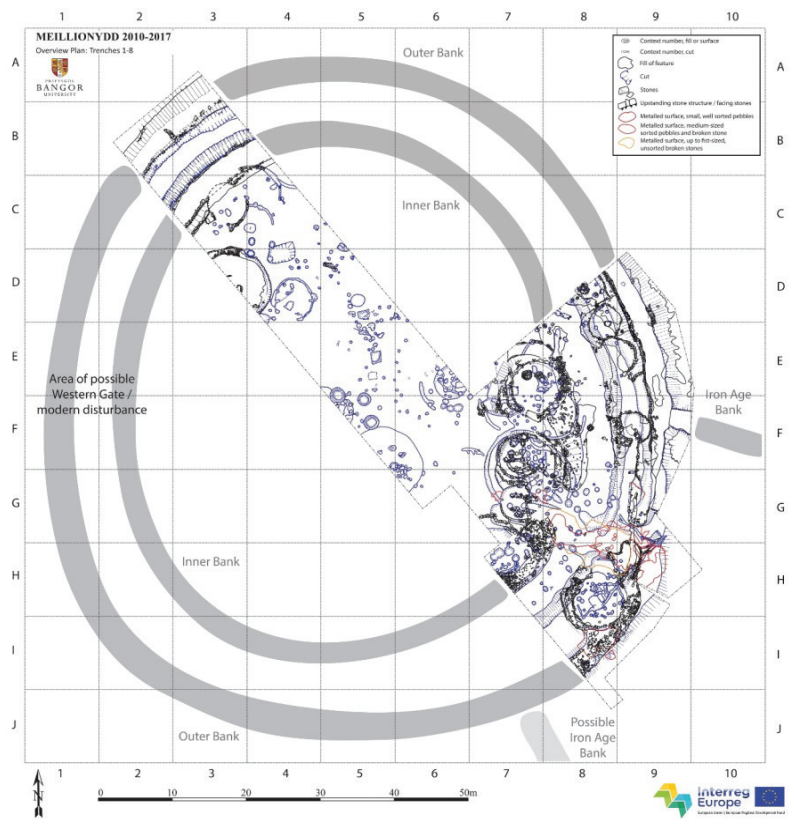


Meillionydd is a subcircular enclosed homestead (Figure 1), a quite common type of settlement in the British Isles which first appears in the Late Bronze Age and continues to be used, more or less continuously, until roughly the end of the Early Medieval period, though not everywhere throughout the whole c. 2000 years from c. 1000 BC - AD 1000 (Champion, 1999, p. 100; Haselgrove, 1999, pp. 115-120; Arnold, 2000, pp. 156-165; Raftery, 1994, pp. 17-63; Stout, 1997; Edwards, 1996, pp. 6-43; etc.). There also are three other, similar settlements (two out of sight from Meillionydd) and several smaller (mostly unenclosed) clusters and a few isolated roundhouses on or in the immediate vicinity of Mynydd Rhiw; and another one across the Western plain of the Llyn in its centre, about 3 miles from Meillionydd as the crow flies and clearly visible from it, Castell Odo (Alcock, 1960); and more roundhouses can be found on Mynydd Anelog at the western end of the Llyn (Waddington, 2013, Plate 5.6).

Based on the analysis of the stratigraphic relationships between different features, we are currently able to distinguish between 13 occupation phases (Figure 2) in Meillionydd. While it had started out as an unenclosed settlement, after an estimated about 140 years, it was enclosed with two concentric, round ditches and a strong timber fence with a substantial gatehouse (which was repaired / replaced at least once, if not twice during the lifetime of the timberfenced double-ditched enclosure).

Another c. 140 years later, the site was completely remodelled and its construction style radically changed. Most significantly, it was surrounded by a monumental double embanked enclosure, with the banks closely following the course of the earlier ditches and up to 4 meters wide at the base, and probably c. 2 meters high, with steep drystone facings on both their inner- and outer side. The entrance was kept in roughly the same place as in the previous phases, but the one through the inner bank was particularly elaborated. After this phase, which lasted for c. 90 years, the site continued to be occupied for at least another 5 phases. Yet, the gate passage through the inner enclosure was blocked up, making the inner bank redundant. However, the internal structure, with differently sized buildings and internal zoning continued, and the outer enclosure seems to have been maintained for several phases longer, indicating that the site did not necessarily loose its functions in this latter part of the site's occupation.

\section{INTERPRETING MEILLIONYDD}

The site of Meillionydd can be interpreted in numerous different ways. While it is self-evident that it was a settlement - after all, it is full of 
Figure 2 - The main occupation phases and sub-phases at Meillionydd.

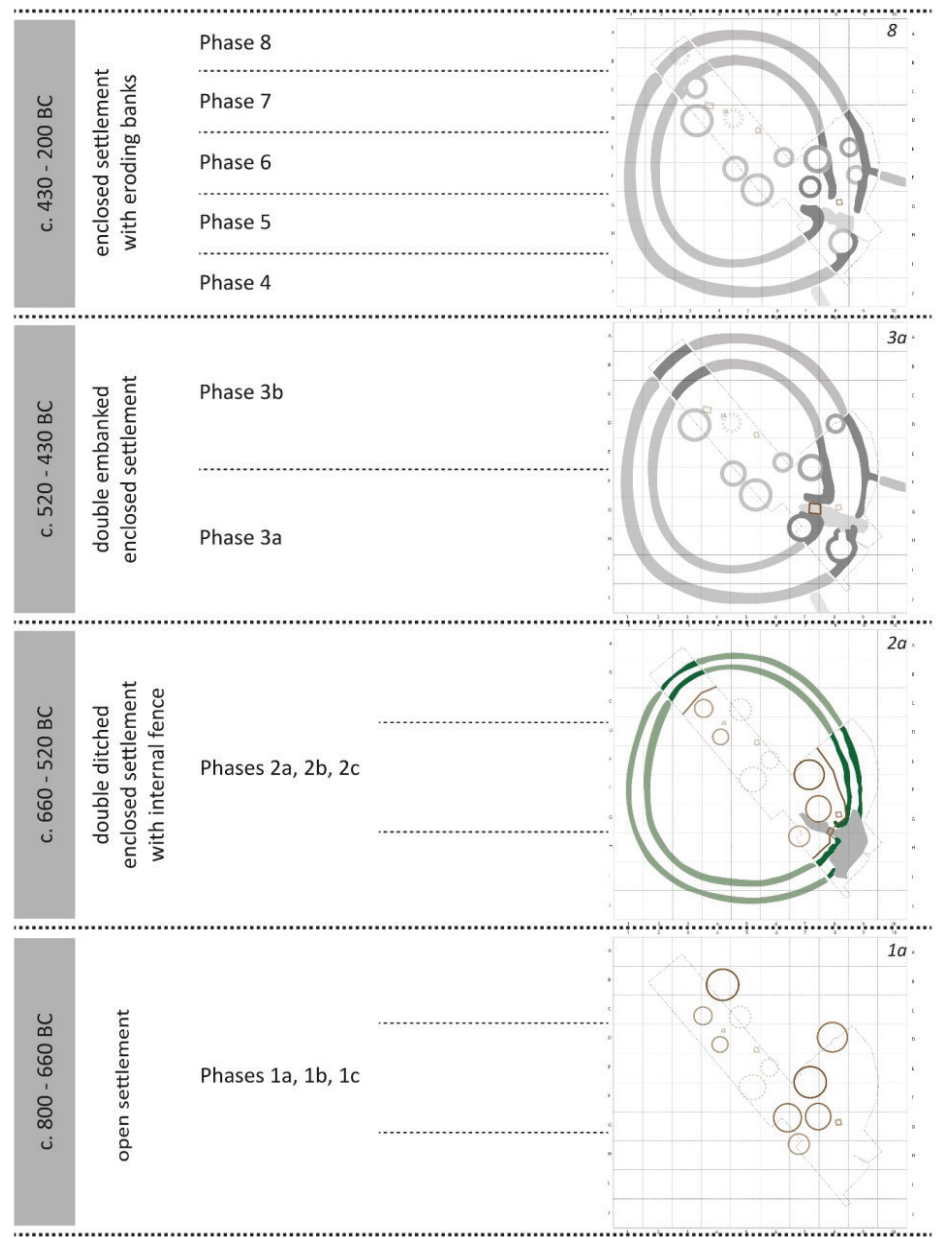

roundhouses with various internal features (for heating and partially other activities like working and storage), various features outside roundhouses which clearly were used for storage, at least partially of grain, and was for most of its occupation enclosed by a strong timber fence, ditches or even 'ramparts' - it could have been used in numerous different ways by quite differently organised communities. Indeed, its changing layout - from open to lightly enclosed to strongly enclosed to enclosed with eroding banks - indicates that at least to some extent, the community who lived in Meillionydd changed, and 
so did the wider society it was part of, and quite possibly also its role and status within that wider society.

To interpret Late Bronze and Iron Age society on the Lly $n$ and the role of Meillionydd's community in it, it is necessary to draw on interdisciplinary analogical reasoning. For instance, it is perfectly possible to draw on anthropological models like those developed by Fried (1967) or Service (1972) to try to interpret what kind of community in what kind of society built and lived in Meillionydd. It is, however, also possible to draw on e.g. Medieval Irish and Welsh literary and historical sources, or general models based on them, to use as analogies to interpret at least some of the communities which inhabited Meillionydd and their role in wider society.

One particularly good possibility is to draw on general models of the both spatial and social - internal structure and organisation of particular kinds of settlements in (Early) Medieval Ireland and Wales. After all, particularly early Irish literature and law describes in quite some detail settlements which, at least morphologically, appear to be remarkably similar to Meillionydd and stand in a continuous architectural tradition with it: the so-called 'ringforts' (Stout, 1997; Edwards, 1996, pp. 6-43). Particularly, they are characterised by having an enclosed courtyard, Old Irish les (eDIL 2020, s.v. '2 les'), which has attested cognates in Welsh llys (GPC 2020, s.v. 'llys'1') and Gaul. lissos (Delamarre, 2003, p. 204), both with probably roughly the same range of meanings: "the space about a dwelling-house or houses enclosed by a bank or rampart, farmyard, courtyard; a ringfort, circular earthwork” (eDIL 2020, s.v. '2 les').

Based on descriptions of and laws on the structures (Kelly, 1998, pp. 360397) making up an Early Medieval Irish dún ("fort, residence of a chief or dignitary; habitation"; eDIL 2020, s.v. 'dún') or ráth ("earthen rampart surrounding a chief's residence, fort”; eDIL 2020, s.v. '2 ráth'), it is possible to create an idealised reconstruction of such a 'ringfort' (Karl, 2008, pp. 109-110; Figure 3 ). It consists mainly of an embanked enclosure around a tech ("house, dwelling"; eDIL 2020, s.v. 'tech') with associated built structures both in and outside the thus defined les, its 'courtyard'. As the Dictionary of the Irish Language puts it, the word dún "in O.Ir." is "usually applied to" a "residence of a chief or dignitary, consisting of an earthen (more rarely stone) rampart, inside which the house ('tech') or houses were erected; oft. of considerable extent and in case of a royal residence having two (or even three) circumvallations with a moat" (eDIL 2020, s.v. 'dún'); and this term again has cognates in both Welsh din, dún (GPC 2020, s.v. 'din') and Gaul. dunon (Delamarre, 2003, pp. 154-156) with, again at least roughly, the same range of meanings. 
Figure 3 - Idealised reconstruction of an Early Medieval Irish 'ringfort', based on the descriptions of and laws on the different structures making up a dún or ráth in the early Irish literary tradition (Kelly, 1998, pp. 360-397; Karl, 2008, pp. 109-110).

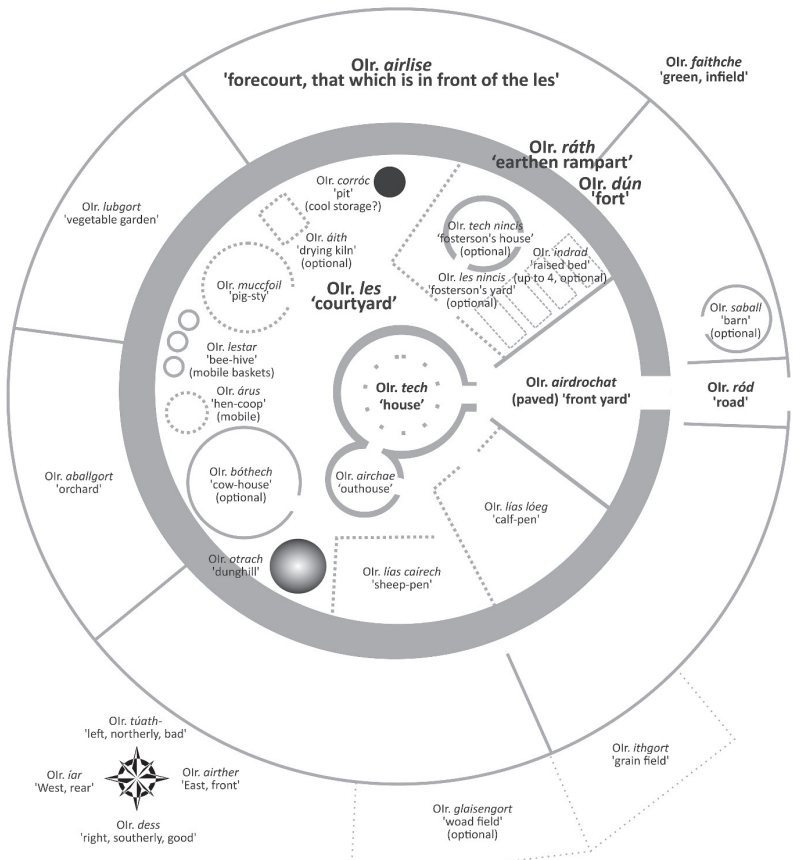

While the llysoedd of the Medieval Welsh princes clearly differ from Irish ringforts, not least in that partially excavated ones like Llys Rhosyr on Anglesey (Johnstone, 1997, pp. 65-67) are built on a rectangular footprint, they nonetheless follow a similar pattern in terms of the buildings they are expected to contain, and their general structural layout. According to Welsh law, "the taeogion [tenants] are obliged to build the following [in the llys of a king]: a hall, and food-house (byty), kitchen (kegyn), sleep-house (hundy), stable, beer-house (kyuordy), latrine, and those within the court (a hynny o ueun y llys); and a barn and a kiln outside on the maerdref (ar y uartref)" (Jones, 2000, pp. 296297), with the main differences to ('ordinary') Irish ringforts being a number of additional buildings required for accommodating and supporting the much larger size of the royal household when in residence at the llys.

This allows to use this idealised layout and terminology as an analogy to - at least tentatively - interpret the structures in Meillionydd from phase 3a 
onwards, since from this point in its occupation sequence onwards, morphologically, it is clearly a llys internally structured, at least roughly, according to this idealised layout. There is a large central roundhouse with evidence for a hearth or fireplace, which would be fitting for a hall; and there are numerous ancillary buildings, mostly along the inner flanks of both inner and outer bank, which could be the various other buildings listed as features of a Welsh princely court (Figure 4); or alternatively could have been used as various agricultural buildings if the site were to be interpreted as a somewhat more modest 'ringfort'. Indeed, the mid-sized roundhouse in the outer southern bank terminal fits perfectly with what would be expected of and only truly makes sense as a porter's lodge, another building expected in medieval Welsh courts, as I already argued in greater detail elsewhere (Karl forthc.).

Figure 4 - Phase 3a at Meillionydd, with Middle Welsh royal court building terminology superimposed.

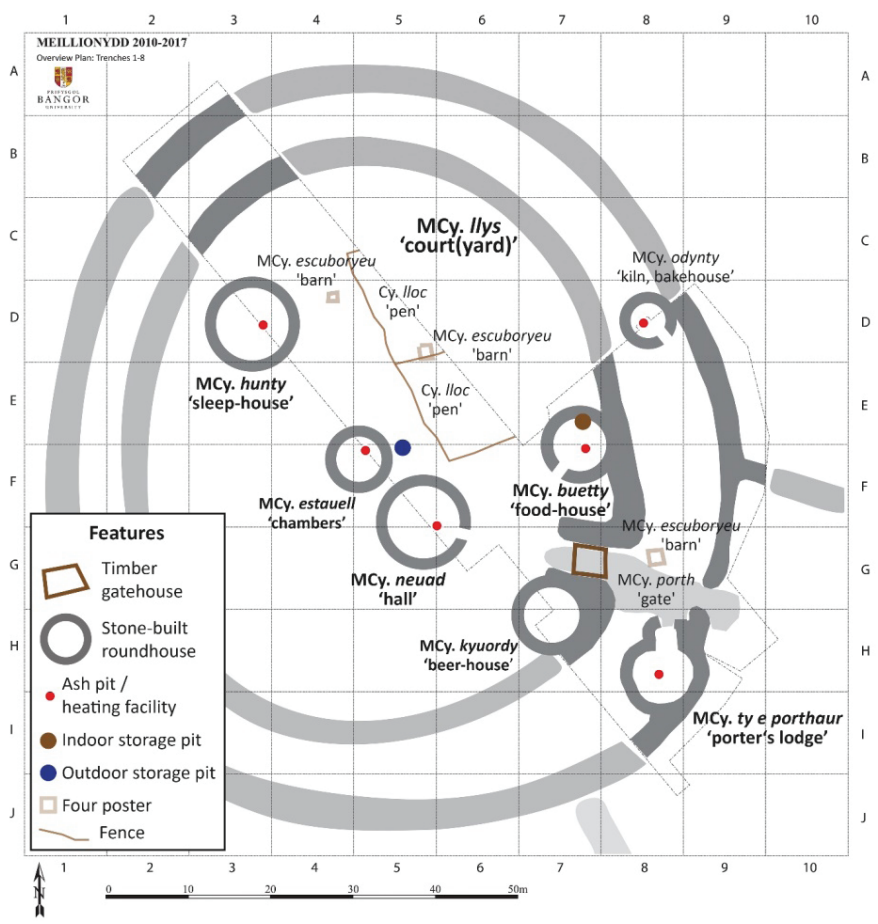

The Medieval analogies also fit well with the stone-built phases at Meillionydd (starting from phase 3) from a social perspective, as does the fact 
that the site is enclosed with a double embankment. From phase 3a onwards, there are three distinct classes of house sizes which can be observed in the record: the large central house and another large house set within the courtyard in the inner enclosure of more than $50 \mathrm{~m}^{2}$ usable floor space, a group of mid-sized roundhouses with c. $30-50 \mathrm{~m}^{2}$ useable floor space, mostly clustering alongside the inner flank of the inner bank, and a group of small roundhouses with only c. 10-30 $\mathrm{m}^{2}$ useable floor space, many of which are found alongside the inner flank of the outer bank (Figure 5). While again, this could be interpreted in several ways, one possible way of interpreting this house size distribution is that the representative central house and the larger buildings in the inner courtyard where the residences and function rooms of a "chief or dignitary” (eDIL 2020, s.v. 'dún') and his family and high-ranking retainers; while the smaller buildings between the banks were huts where servants, semi-free tenants and/or slaves serving the dignitary lived. Tenants of a lord, as we have

Figure 5 - Distribution of roundhouses (with various internal features) of phases 3a-8 in Meillionydd. Note particularly the clustering of differently sized houses in different parts of the site.

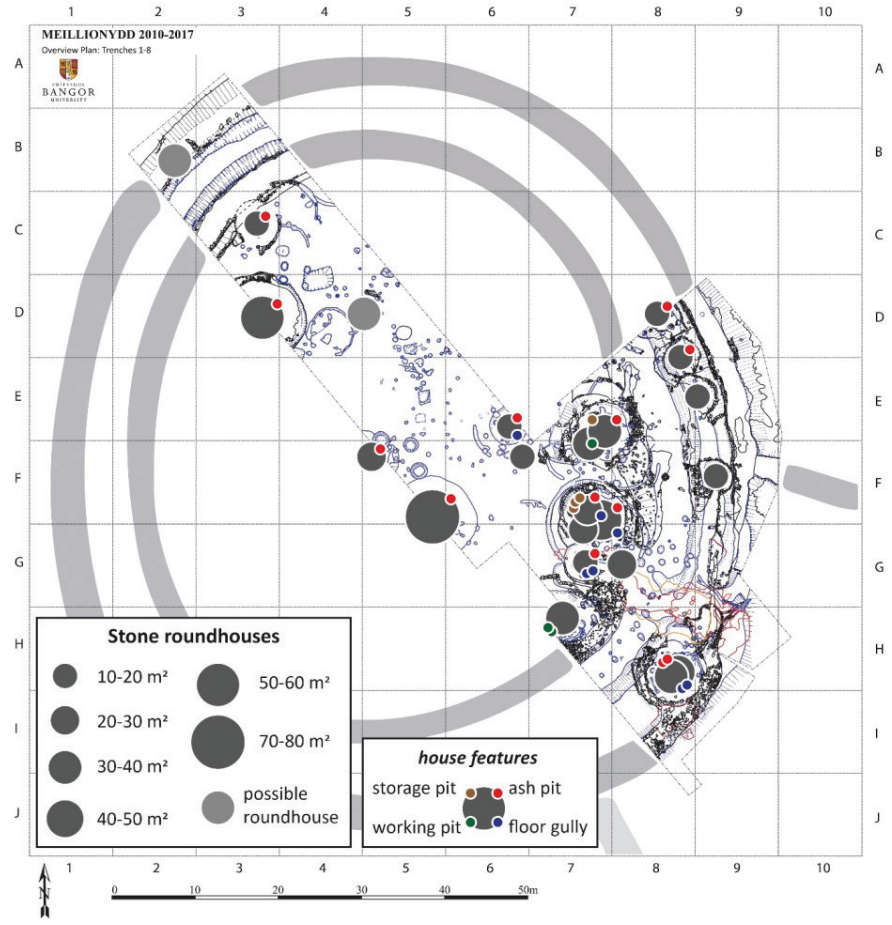


already seen above, were obliged to build (and presumably also maintain) his residential and representational buildings in the court (Jones, 2000, pp. 296297), and according to Irish sources the tenants/clients of a lord also obliged to construct and maintain the "ramparts of vassalage" (MacNeill, 1923, p. 305) surrounding his courtyard (Kelly, 1988, p. 30).

While the later occupation phases (from 3a to 8; Figure 2) at Meillionydd fit nearly perfectly with the idealised structure and organisation of the 'courts' (of princes, chiefs or other dignitaries) described in the Medieval sources from both Ireland and Wales, the earlier, timber-built phases do not. This becomes immediately apparent if one, again, looks at the spatial and size distribution of the roundhouses from these earlier phases on the site (Figure 6). Immediately apparent is the absence of a large central roundhouse as a focal point for the site. But also, compared with the later phases, roundhouses on average are considerably larger, and there is a completely different distribution of house sizes (Figure 7): while $86 \%$ of the stone roundhouses of the later phases have less than $40 \mathrm{~m}^{2}$ and $55 \%$ less than $39 \mathrm{~m}^{2}$ useable floor space, $63 \%$ of the earlier phase timber roundhouses have $40-70 \mathrm{~m}^{2}$ and $81 \%$ more than $30 \mathrm{~m}^{2}$ usable floor space. This indicates a significant shift in the use and distribution of domestic space from phase 2 to phase 3 at Meillionydd: while (at least roofed) space seems to have been distributed relatively egalitarian until the end of phase 2, there is a much more hierarchical distribution of it from phase 3 onwards.

Thus, the interdisciplinary analogies gathered from Medieval Irish and Welsh sources, if perhaps not completely incommensurable with the archaeological record of the earlier occupation phases at Meillionydd, do not fit nearly as well with it and appear mostly unsuitable to explain both the spatial as well as the size distribution of the buildings on site. The Medieval analogies thus are mostly inapplicable to the earlier phases at Meillionydd, but do become very well applicable to its later occupation phases.

This indicates that there was a change in the internal (social) structure of the community inhabiting Meillionydd, its role or function in wider society on the $L l \hat{y} n$, and perhaps even - given that the only other similar site on the Llŷn already partially excavated, Castell Odo (Breese, 1932; Alcock, 1960), seems to have gone through the same changes as Meillionydd roughly contemporarily with it - in the wider society inhabiting the Lly $n$ in the late 6th century BC. It may well be that we are witnessing, in the construction sequence of sites like Meillionydd, the emergence of both the kinds of societies and the social elites that are characteristic for both (Early) Medieval Irish and 
Figure 6 - Distribution of roundhouses (with internal features) of phases $1 \mathrm{a}-2 \mathrm{c}$ in Meillionydd. Note the different spatial organisation and larger house sizes compared to the later occupation phases shown on Figure 5.

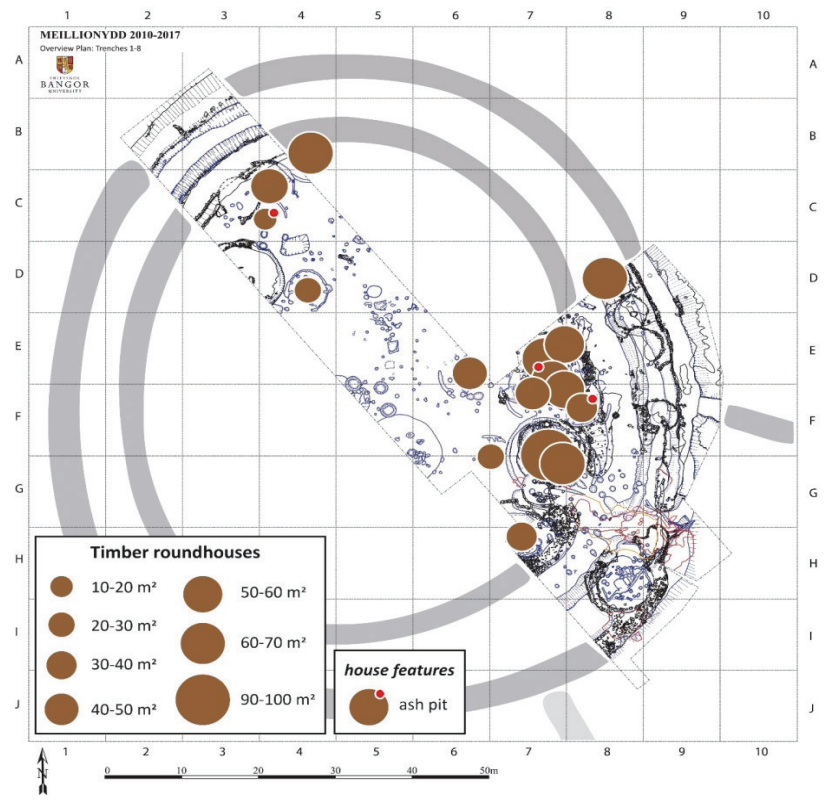

Figure 7 - Size distribution of timber and stone roundhouses at Meillionydd in $10 \mathrm{~m}^{2}$ groups. Note the relatively even distribution of timber roundhouse sizes, with a majority of houses in the $40-70 \mathrm{~m}^{2}$ usable floor space group, while almost all stone roundhouses fall into the $10-40 \mathrm{~m}^{2}$ range.

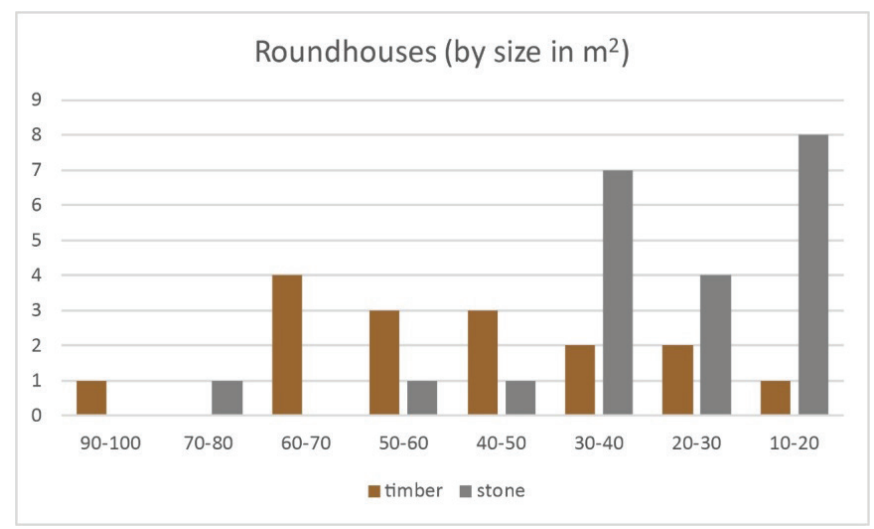


Welsh and also for Iron Age societies in Gaul (at least according to Caesar, De Bello Gallico 6, 11-20).

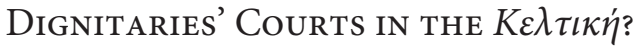

Continental 'Celtic' settlement archaeology differs considerably from that in the British Isles in Antiquity, not least by the fact that while late Prehistoric British domestic architecture is mostly built on round or at least sub-circular footprints (for an idealised view of a homestead, see Figure 3), its continental equivalent is almost invariably built on rectangular footprints. Yet, rectangular enclosed homesteads of similar dimensions and, arguably, also similar internal spatial organisations as comparable British sites, are also known from several

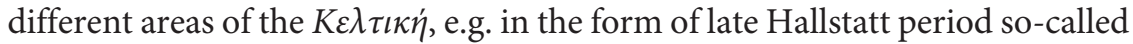
Herrenhöfe (e.g. Berg-Hobohm, 2003) in West Central Europe north of the Alps, their later La Tène successors in (mostly) Southern Germany, the socalled Viereckschanzen (e.g. Wieland, 1999; Figure 8), and also the French fermes indigenes (e.g. von Nicolai, 2006).

Figure 8 - La Tène period Viereckschanze in Riedlingen, aden-Württemberg, Germany (Wieland, 1999, p. 154).

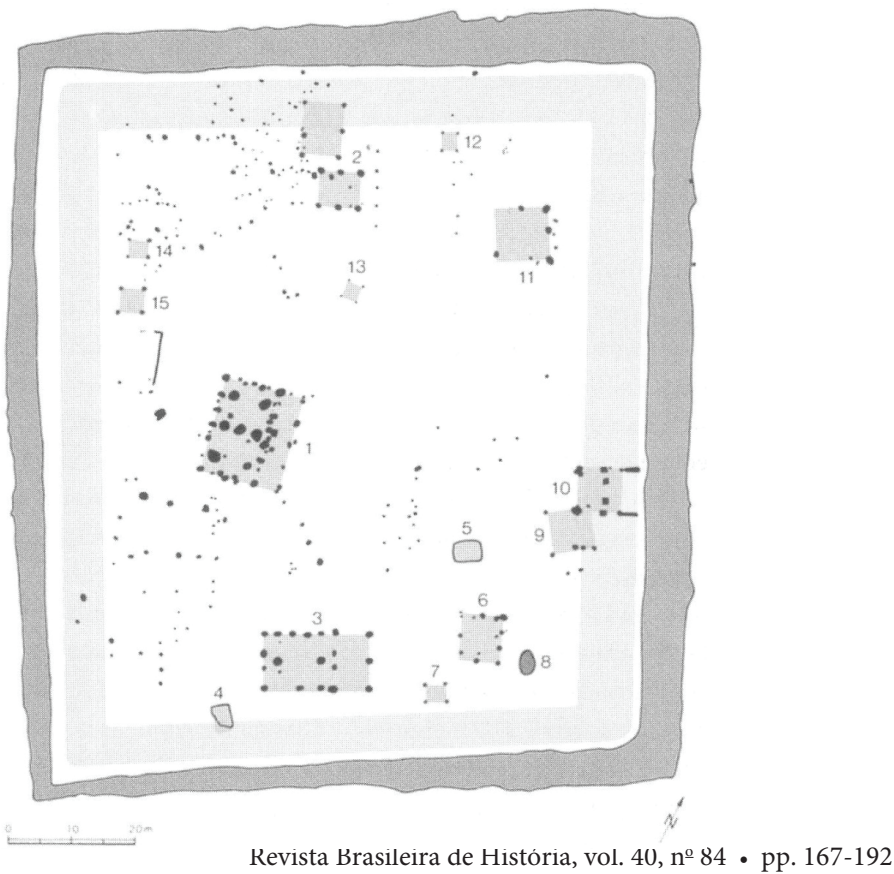


These rectangular courtyard enclosures also are characterised by a large, representational building opposite and facing the entrance into the enclosure across a courtyard, with various ancillary buildings, usually of considerably smaller size than the main 'hall', arranged along the inner flank of the enclosing fence, palisade or bank and ditch (Figure 9). Quite a number of such courtyard enclosures also were surrounded by other, unenclosed homesteads (Wieland, 1999; Berg-Hobohm, 2003), which could be interpreted as the equivalent of the maerdref associated with the llys of a king, prince or other territorial ruler in Medieval Wales: the tenant village where a part of the wider membership of the household of said dignitary resided; some of his dependents who had to erect and maintain the buildings and walls of the llys (Jones, 2000, pp. 296-297) as one of their menial duties they owed for having been given a grant of land they could farm to support themselves and their family by their lord.

Figure 9 - Idealised model of a continental 'Celtic' courtyard enclosure (adapted from Karl, 2008, p. 119). Note the similar spatial organisation and the size distribution of different buildings, which appear similar to the spatial organisation and building size distribution in the later occupation phases at Meillionydd (Figure 4).

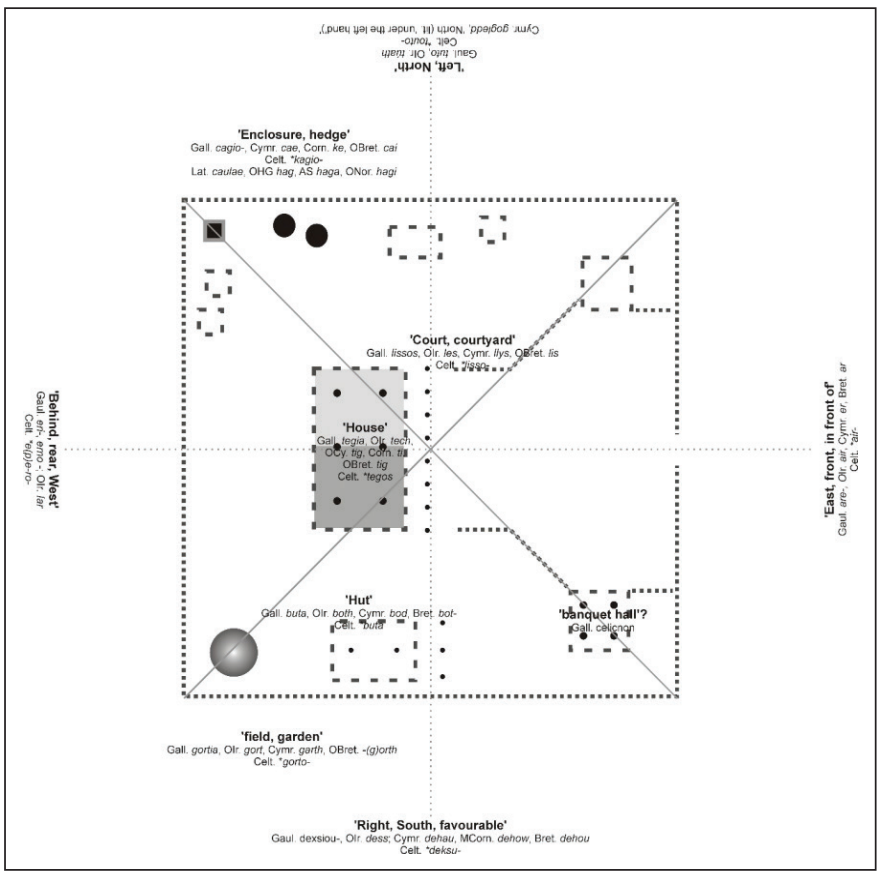


This kind of (early) feudal, household-based society in turn fits nicely with both specific as well as more general descriptions of Late Iron Age 'Celtic' communities and their social system, as e.g. found in Caesar's commentary on his Gaulish Wars. Whether it is his more general description of Gaulish society as a whole, that amongst the knightly class in Gaul, those dignitaries "most distinguished by descent and wealth have the largest number of vassals and tenants about them", acknowledging "this sort of influence and power only" (De Bello Gallico 6, 15); or more specific ones like his report that Orgetorix could draw on ten thousand vassals and many dependants and debtors from all over the Helvetian territory when he was indicted in court of planning a coup d'état (De Bello Gallico 1, 4), the analogies, both between the medieval Irish and Welsh sources and the classical ones and between the insular and continental archaeological sources fit quite well.

\section{Crossing the Divide between Ancient History AND Archaeology}

Of course, what was discussed in this paper regarding the possibility of

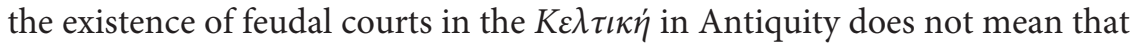
any such courts, if they already existed in the Late Bronze and Iron Age, were structured exactly like those described in Medieval Welsh law texts, with exactly the same officers, officials and rights and duties of each (Jenkins, 1986, pp. 5-41), nor that the buildings we find in Hallstatt period Herrenhöfe had the very same functions as those in Welsh llysoedd two and a half millennia later. Indeed, even only transcribing the court building terminology on a Welsh courtyard enclosure of the late 6th century BC (Figure 4) must remain tentative; one hypothesis of at least several, if not many, which could equally explain the settlements' layout, structure and buildings.

Nor does it mean that this Medieval court organisation and architectural layout can be assumed to be 'the Celtic' court system, if it existed at all: indeed, courtyard enclosures of the kind discussed here (Figures 1, 3, 8, 9) are not at-

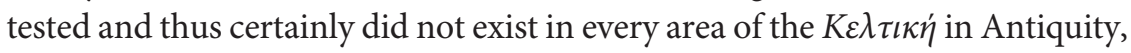
or even only in every part of Late Prehistoric Britain and Ireland. The interdisciplinary analogies used in this paper to interpret the Welsh Late Bronze and Iron Age double ringwork enclosure of Meillionydd, and by proxy also the courtyard enclosures of the Late Bronze and Iron Age existing in parts of Hallstatt and La Tène continental Europe, thus are almost certainly completely 


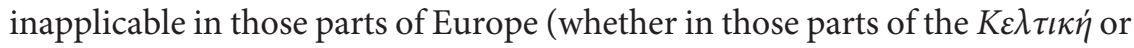
those parts of the British Isles) where such courtyard enclosures were never constructed.

Rather, at best, the interdisciplinary analogies used in and used as they have been in this paper allow to support an interdisciplinary hypothesis that some Later Prehistoric communities in parts of the $K \varepsilon \lambda \tau \iota \kappa \eta$ and of the British Isles had developed, at different times and - as the case of Meillionydd and the social change visible there in c. the late 6th century BC indicates - based mainly on local conditions and developments, early feudal social systems; characterised by a distinct class hierarchy, clientage relationships and other forms of social dependency as described in both Caesar's discussions of Late Iron Age Gaulish societies and in Medieval Irish and Welsh historical sources. They also allow us to support the interdisciplinary hypothesis that where we find them, the courtyard enclosures of the European Late Bronze and Iron Age may indeed have been "residence[s] of a chief or dignitary" (eDIL 2020, s.v. 'dún'), which may well have been referred to as a lissos or a dunon (Delamarre, 2003, pp. 154-156, 204), if their inhabitants happened to speak a Celtic language, too (which, however, is by no means a given, since language and settlement architecture and design are not coupled). And they provide us with one possible interpretation of the internal structures and makeup of individual communities like the one which inhabited Meillionydd from the late 6th century BC onwards until c. 200 BC.

Of course, other hypotheses about the courtyard enclosures of the European Late Bronze and Iron Age, and about the communities inhabiting

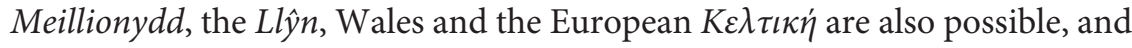
interdisciplinary reasoning as demonstrated in this paper does not conclusively prove that the one hypothesis proposed here is actually correct. But historical scholarship can virtually never prove any hypothesis about the past to be positively correct. Crossing the boundaries between Ancient History, Medieval History, Historical Linguistics and Archaeology, as demonstrated in this paper, can provide us with reasonable and evidence-based interpretations and hypotheses which can shed light on possible, and perhaps even likely versions of the 'Celtic' past. They enable archaeologists to make mute stones tell us stories, and that is not just the best we can hope for, but also the best we can do, because it breathes life again into things (and people) who have long been dead and will otherwise remain forgotten. 


\section{REFERENCES}

ALCOCK, Leslie. Castell Odo: an embanked settlement on Mynydd Ystum, near Aberdaron, Caernarvonshire. Archaeologia Cambrensis, vol. 109, pp. 78-135, 1960.

ARNOLD, Christopher J. 2000. Early Medieval Wales, AD 400-1000: An Introduction. In: ARNOLD, Christopher J.; DAVIES, J. L. Roman and Early Medieval Wales. Stroud: Sutton Publishing, 2000. pp. 141-197.

BERG-HOBOHM, Stefan. Umfriedete Höfe der Hallstattzeit in Bayern. Aktueller Forschungsstand zu den Herrenhöfen und den zeitgleichen rechteckigen Grabenwerken. Berichte Bayerische Bodendenkmalpflege, vol. 43/44, pp. 161-189, 2003. BERNBECK, Reinhard. Theorien in der Archäologie. Tübingen: Francke UTB, 1997. BREESE, Charles E. Castell Odo. Archaeologia Cambrensis, vol. 87, pp. 372-385, 1932. CHAMPION, Timothy. The Later Bronze Age. In: HUNTER, John; RALSTON, Ian (ed.). The Archaeology of Britain: An Introduction from the Upper Palaeolithic to the Industrial Revolution. London: Routledge, 1999. pp. 95-112.

COLLIS, John R. The Celts: Origins, Myths \& Inventions. Stroud: Tempus, 2003.

DELAMARRE, Xavier. Dictionnaire de la langue gauloise. 2nd ed. Paris: Éd. Errance, 2003.

eDIL 2020. Electronic Dictionary of the Irish Language, edited by G. Toner, M. Ni Mhaonaigh, S. Arbuthnot, M.-L. Theuerkauf, D. Wodtko. Dublin: Royal Irish Academy. Available at: http://www.dil.ie/. Accessed on: Jan. 31, 2020.

EDWARDS, Nancy M. The Archaeology of Early Medieval Ireland. Pbk. ed. London: B.T. Batsford, 1996.

FRIED, Morton H. The Evolution of Political Society: An Essay in Political Economy. New York: Random House, 1967.

GPC 2020. Geiriadur Prifysgol Cymru Ar Lein: A Dictionary of the Welsh Language Online. Cardiff: University of Wales, 2020. Available at: http://geiriadur.ac.uk/gpc/ gpc.html . Accessed on: Jan. 31, 2020.

HASELGROVE, Colin. The Iron Age. In: HUNTER, John; RALSTON, Ian (ed.). The Archaeology of Britain: An Introduction from the Upper Palaeolithic to the Industrial Revolution. London: Routledge, 1999. pp. 113-134.

HOFENEDER, Andreas. Die Religion der Kelten in den antiken literarischen Zeugnissen. Band I: Von den Anfängen bis Caesar. Mitteilungen der prähistorischen Kommission, 59. Wien: Öst. Akad. Wiss., 2005.

JAMES, Simon. The Atlantic Celts Ancient People or Modern Invention? London: British Museum Press, 1999.

JENKINS, Daffydd. The Law of Hywel Dda: Law texts from mediaeval Wales. Transl. Llandysul: Gomer Press, 1986.

JOHNSON, Matthew. Archaeological Theory: an Introduction. Oxford: Blackwell, 1999. 
JOHNSTONE, Neill. An Investigation into the Location of the Royal Courts of Thirteenth Century Gwynedd. In: EDWARDS, Nancy (ed.). Landscape and Settlement in Medieval Wales. Oxford: Oxbow Books, 1997. pp. 55-69.

JONES, Glanville R. J. Llys and Maerdref. In: CHARLES-EDWARDS, T. M.; OWEN, M. E.; RUSSELL, P. (ed.). The Welsh King and his Court. Cardiff: University of Wales Press, 2000. pp. 296-318.

KARL, Raimund. The Celts from Everywhere and Nowhere: A Re-evaluation of the Origins of the Celts and the Emergence of Celtic Cultures. In: KOCH, John T.; CUNLIFFE, Barry W. (ed.). Celtic from the West: Alternative Perspectives from Archaeology, Genetics, Language and Literature. Oxford: Oxbow Books, 2012. pp. 39-64.

KARL, Raimund. Hausfrieden. Die Siedlung als magisch-religiös geschützter Raum. Keltische Forschungen, vol. 3, pp. 93-131, 2008.

KARL, Raimund. Pa gwr yv y porthaur? The Emergence of a Court and the Office of the Porter at Meillionydd. In: KARL, Raimund (ed.). Interpreting Meillionydd: Collected papers. Bangor: RK. (forthcoming).

KARL, Raimund. Social changes in Late Bronze and Early Iron Age Wales: The beginning of Celtic Wales? In: KARL, Raimund; MÖLLER, Katharina (ed.). Proceedings of the second European symposium in Celtic Studies, held at Prifysgol Bangor University from July 31st to August 3rd 2017. Hagen/Westf.: curach bhán, 2018. pp. 159-179.

KELLY, Fergus. Early Irish Farming. Early Irish Law Series, vol. IV. Dublin: Institute for Advanced Studies, 1998.

KELLY, Fergus. A Guide to Early Irish Law. Early Irish Law Series, vol. III. Dublin: Institute for Advanced Studies, 1988.

KOCH, John T.; KARL, Raimund; MINARD, Antone; Ó FAOLÁIN, Simon. An Atlas for Celtic Studies: Archaeology and Names in Ancient Europe and Early Medieval Ireland, Britain and Brittany. Oxford: Oxbow Books, 2007.

KRAUSSE, Dirk; FERNÁNDEZ-GÖTZ, Manuel; HANSEN, Leif; KRETSCHMER, Inga. The Heuneburg and the Early Iron Age Princely Seats: First Towns North of the Alps. Budapest: Archeolingua, 2016.

MACNEILL, Eoin. Ancient Irish Law: the Law of Status or Franchise. Proceedings of the Royal Irish Academy, 36 C, pp. 265-316, 1923.

MEGAW, Ruth; MEGAW, Vincent. Celtic Art from its Beginnings to the Book of Kells. Rev. \& exp. ed. London: Thames and Hudson, 2001.

RAFTERY, Barry. Pagan Celtic Ireland: The Enigma of the Irish Iron Age. London: Thames \& Hudson, 1994.

SERVICE, Elman R. Primitive Social Organisation: An Evolutionary Perspective. 2nd ed. New York: Random House, 1972.

STOUT, Matthew. The Irish Ringfort. Dublin: Four Courts Press, 1997. 
TOMASCHITZ, Kurt. Die Wanderungen der Kelten in der antiken literarischen Überlieferung. Mitteilungen der prähistorischen Kommission, 47. Wien: Öst. Akad. Wiss., 2002.

VON NICOLAI, Caroline. Sakral oder profan? Späteisenzeitliche Einfriedungen in Nordfrankreich und Süddeutschland. Leipziger online-Beiträge zur Ur- und Frühgeschichtlichen Archäologie, 22. Leipzig: Universität Leipzig, 2006.

WADDINGTON, Kate. The Settlements of Northwest Wales: From the Late Bronze Age to the Early Mediaeval Period. Cardiff: University of Wales Press, 2013.

WIELAND, Günther. Keltische Viereckschanzen: Einem Rätsel auf der Spur. Stuttgart: Theiss, 1999.

\section{NOTE}

${ }^{1}$ Indeed, in practical terms, it does not - and even in the 5th century BC did not matter whether Herodot (and/or his sources) actually knew of and meant the town at the Heuneburg, or had confused it with another town somewhere north of the Pyrenees near the sources of e.g. the Garonne or the Aude. This is because a traveller or merchant from the wider Greek world, who wanted to get to the land of the 'Celts' near the town called $\Pi v \rho \eta v \eta$, choosing to sail up the Danube following Herodot's directions rather than taking the route through the Mediterranean, would eventually

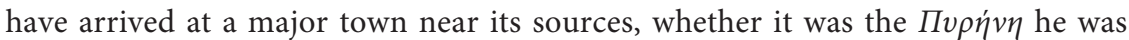
looking for or not. If it was, he'd arrived where he wanted to get to and presumably, particularly if coming from one of the Greek colonies in the Black Sea, saved quite a lot of time. And if it was not, since that town had contacts with $M \alpha \sigma \sigma \alpha \lambda i \alpha$, the traveller could have continued from there across the Rhine and down the Rhone and even-

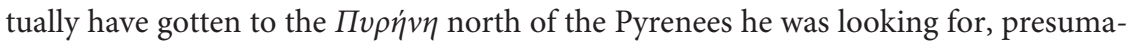
bly not even having lost much time on the way.

Article received on February 4, 2020.

Approved on May 25, 2020. 